\title{
Dynamics and cytochemistry of oogenesis in Leporinus striatus Kner (Teleostei, Characiformes, Anostomidae) from the Rio Sapucaí, Minas Gerais State, Brazil
}

\author{
Helena A.S. Chini ${ }^{1}$ \\ José Antonio Dias Garcia ${ }^{2}$ \\ Edson Luis Maistro ${ }^{3}$ \\ Irani Quagio-Grassiotto ${ }^{4}$
}

\begin{abstract}
Oogenesis involves a sequense of transformations which are undergone by female germ cells. These cells change into oogonias and then into mature oocytes. Sexually mature females were collected monthly, during one year, from the Rio Sapucaí, tributary of the Rio Grande, which is part of the Furnas Reservoir system in the state of Minas Gerais. The observed material showed that oogonias were small spherical cells, had a big spherical nucleus, with a single nucleolus, and weakly stained cytoplasm with eosinophilic granules (FG stained), which indicate their protein content. The primary oocytes showed a big basophilic nucleus, with a large peripheral nucleolus, and several smaller nucleoli. They show a reduced cytoplasmic content. The previtellogenic oocytes presented voluminous cytoplasm and nucleus with several small peripheral nucleoli. The oocytes underwent vitellogenesis with the development of the zona radiata and the follicle cells. The zona radiata had two layers, the outer and the inner, which showed its protein content when stained with $\mathrm{CM}$ and FG techniques. $\mathrm{TB} \mathrm{pH} 2.5$ and $\mathrm{pH} 4.0$ staining showed that oocytes undergoing vitellogenesis presented weakly stained cytoplasm and peripheral cytoplasmic vesicles. The follicle cells that were squamous became cuboidal. In mature oocytes, the yolk granules that filled the cytoplasm became green and blue when stained with FG and CM techniques, indicating their protein content. The perivitelline region showed rosy stained vesicles (TB pH 2.5 and $\mathrm{pH} 4.0$ ) spread among the weakly stained peripheral vesicles, which seemed to be the cortical alveoli. The zona radiata cells, CM and FG stained, still showed two layers like the oocytes from the previous stage, but thicker.

KEY WORDS. Teleostei, Anostomidae, Leporinus striatus, oogenesis, cytochemical
\end{abstract}

Anostomidae are herbivorous fishes, of small and medium size, very appreciated as food and in game fishing (BRITSKI 1972), and usually found in neotropical rivers. Small size species, such as Leporinus striatus Kner, 1859, are also found in reservoirs, where they form the basis of the food chain (NOMURA 1984).

1) Instituto de Odontologia e Ciências da Saúde, UNIFENAS. Caixa Postal 23, 37130-000 Alfenas, Minas Gerais, Brasil.

2) Faculdade de Medicina Veterinária, Departamento de Medicina Veterinária Preventiva, UNIFENAS. Caixa Postal 23, 37130-000 Alfenas, Minas Gerais, Brasil.

3) Instituto de Farmácia e Nutrição, UNIFENAS. Caixa Postal 23, 37130-000 Alfenas, Minas Gerais, Brasil. Brasil. E-mail: maistro.edson@unifenas.br

4) Departamento de Morfologia, Instituto de Biociências, Universidade Estadual Paulista. Campus Rubião Júnior, 18300-000 Botucatu, São Paulo, Brasil. 
Fish reproduction is generally cyclic, seasonal and influenced by environmental conditions (NAGAHAMA 1983). The female gametogenesis, due to the different morphological characteristics shown by the germ cells, from oogonias to mature oocytes, is used as a parameter to determine the time of the year in which they reproduce (WEST 1990). Therefore, describing cell types and, mainly, the chemical and morphological characteristics of oocyte structures, such as cortical alveoli, yolk globule and zona radiata, as well as the characteristics of follicle cells, is the starting point in the study of the reproductive biology of fish (GURAYA 1986).

Within this context, the purpose of the present work was to study the dynamics and cytochemistry of oogenesis in Leporinus striatus Kner, 1859, at the Rio Sapucaí, Furnas Reservoir, Minas Gerais State, Brazil.

\section{MATERIAL AND METHODS}

Leporinu striatus specimens were collected monthly during one year, from August 1998 to July 1999, in the Rio Sapucaí, a tributary of the Rio Grande, Furnas

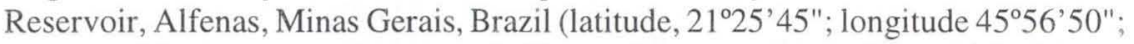
average altitude, $849,2 \mathrm{~m}$ ). A set of gill nets (10 meters long, $1.5 \mathrm{~m}$ high, $1.5 \mathrm{~cm}$ mesh size) were exposed for a 10-15 hours period.

A total of 72 sexually mature females, removed alive from the nets, were taken to the laboratory, where they had their cellomic cavity opened and gonads removed, sectioned and fixed overnight in KARNOVSKY (1964).

The fixed material was embedded in historesin, and cut on a microtome equipped with glass knife. The $3-\mu \mathrm{m}$ sections were differently stained with: hematoxylin-eosin (HE), for general morphological analysis; Toluidin blue pH 4.0 (TB $\mathrm{pH} 4.0$ ), for the detection of acid polysaccharides and phosphated cellular components (DNA and RNA); Toluidin blue $\mathrm{pH} 2.5$ (TB pH 2.5), for the detection of sulphated acid polysaccharides; Coello's Method (CM) (CoELlo 1989), for the detection of neutral polysaccharides and proteins; and Fast Green pH 2.5 (FG), for the detection of total proteins. The slides thus prepared were observed, analyzed and photographed under an Olympus BX 50 photomicroscope.

\section{RESULTS AND DISCUSSION}

Germ cells at different stages of development were observed in the ovaries of the sexually mature specimens of $L$. striatus.

Their oogonias, similarly to teleosts in general (DE VLAMING 1983; VAZZOLER 1996; SILVA et al. 1998), were found grouped in nests and inserted in ovarian lamellae. These were small cells with a big, round and basophilic nucleus (Fig. 1) that underwent meiosis and thus originated the primary oocytes, which were enveloped by a layer of follicle cells forming the follicles. These primary oocytes left the nests and started to develop (Fig. 1).

The oocyte maturation in fishes is a continuous process. However, it can be classified in stages that vary according to the criteria used. BAZZOLI \& GODINHO (1995) and VAZZOLER (1996) described six stages in this process, which can also be applied to L. striatus. 

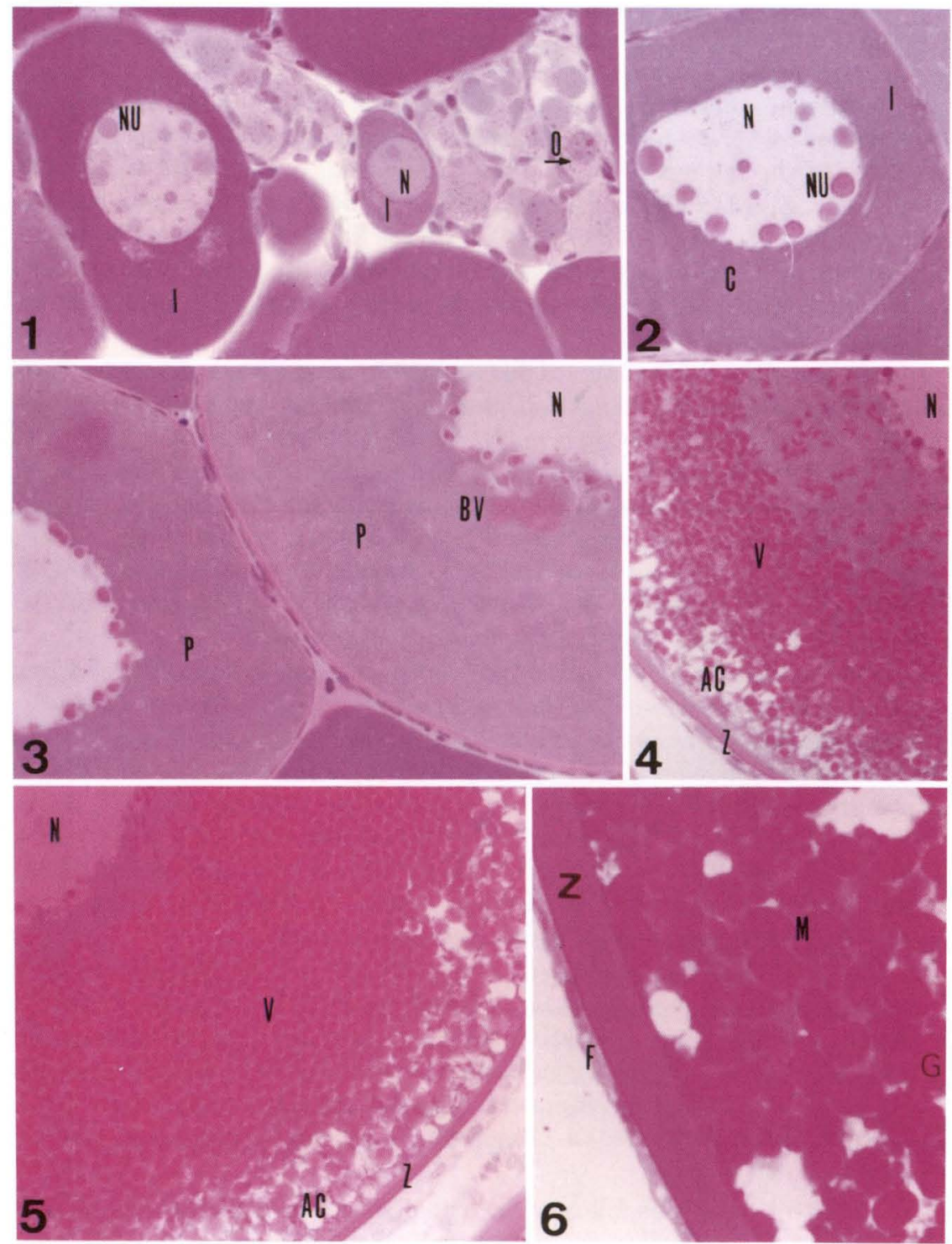

Figs 1-6. (1) oogonia (O), primary oocyte (I), nucleoli (NU), HE; (2) primary oocyte (I), cytoplasm $(C)$, nucleus (N), nucleoli (NU), HE; (3) previtellogenic oocyte (P).nucleus (N), Balbiani's vitelline body (BV) $\mathrm{HE}$; (4) vitellogenic oocyte (V), nucleus $(\mathrm{N})$, cortical alveoli $(\mathrm{AC})$, zona radiata (Z), HE; (5) vitellogenic oocyte (V), nucleus (N), cortical alveoli (AC), zona radiata (Z), HE; (6) mature oocyte $(M)$, yolk globules $(G)$, zona radiata $(Z)$, follicle cells $(F), H E$. 
As observed in the majority of teleosts (VAZZOLER 1996), we found that, in L. striatus, the primary oocytes show reduced cytoplasm, a big, central and basophilic nucleus and a central nucleolus (Fig. 1). These oocytes grow, increase significantly in volume, and show a decreased nucleus-cytoplasm relationship. Within them, several small and big nucleoli appear and start to migrate to the periphery of the nucleus (Fig. 2). These findings agree with those reported by Wallace \& Selman (1981), Nagahama (1983), De Vlaming (1983), Selman \& WALLACE (1989), BAZzoli \& Rizzo (1990) and Rizzo \& BAZzOLI (1993) about this type of cell. The increased number of nucleoli found in primary oocytes is likeky to be related to the rise of RNA synthesis activity, necessary to their posterior maturation progress.

In our study, it was observed that previtellogenic oocytes had a nucleus with several small and peripherical nucleoli, basophilic cytoplasm and showed the formation of Balbiani's vitelline body (Fig. 3). According to DE VLAMING (1983), such structure is a complex composed of cytoplasmic organelles, including mitochondria, multivesicular bodies, endoplasmatic reticulum, Golgi apparatus and fibrogranular material. Similarly to what was observed in previtellogenic oocytes of other teleosts (YAMAMOTO \& YOSHIOKA 1964; ANDERSON 1968; BEAMS \& KESSEL apud WALLACE \& SELMAN 1981; GURAYA 1986; TYLER \& SUMPTER 1996; VAZZOLER 1996), this same structure is formed in the cytoplasm of L. striatus (Fig. 3).

We observed that $L$. striatus began vitellogenesis as clear vesicles appeared in the peripherical cytoplasm, the vitellogenic oocytes shown in figure 4. Generally, the endogen vitellogenesis preceed the exogen, with superposition only in some cases. During the endogen vitellogenesis the yolk vesicles are the first structure that appear in cytoplasm and then reunite on oocyte perifery to form the cortical alveoli (WALlaCe \& SElMAN 1981; HibiYa 1983; NAGAHAMA 1983; DE Vlaming 1983; ZANUY 1987; SELMAN \& WALlACE 1989; SUMPTER et al. 1984; TYLER \& SUMPTER 1996). According to BAZZOLI \& GodinHO (1995), the Balbiani's vitelline body takes part in the formation of the cortical alveoli in teleosts.

In L. striatus, the nucleus of oocytes in primary vitellogenesis showed irregular outline, and contained several peripherical and round nucleoli, making evident its intense activity of synthesis (Fig. 4). Still at this stage, we observed the development of zona radiata, a continuous acidophilic pellicle, with two acellular layers, attached to the oocyte plasmatic membrane. The concomitant onset of zona radiata and cortical alveoli (Figs 4-5) might be a characteristic of this stage of oocyte development (WEST 1990).

The yolk deposition followed the formation of zona radiata and the onset of cortical alveoli. The vitellus, as observed in $L$. striatus, initially appeared in the cortical cytoplasm, and moved centerwise causing an increase in the oocyte volume (Figs 4-5). According to BAzZOLI \& Rizzo (1990), these oocytes are called vitellogenic. The mature oocytes of $L$. striatus showed a contracted nucleus with small (Fig. 7), round and peripherical nucleoli and loss of cytoplasmatic basophilia. They became significantly bigger due to the rapid increase of the number of acidophilic yolk globules (Fig. 6). The zona radiata became thicker and a funnel-like depression was formed, the micropyle (Fig. 12). The initially squamous follicle 

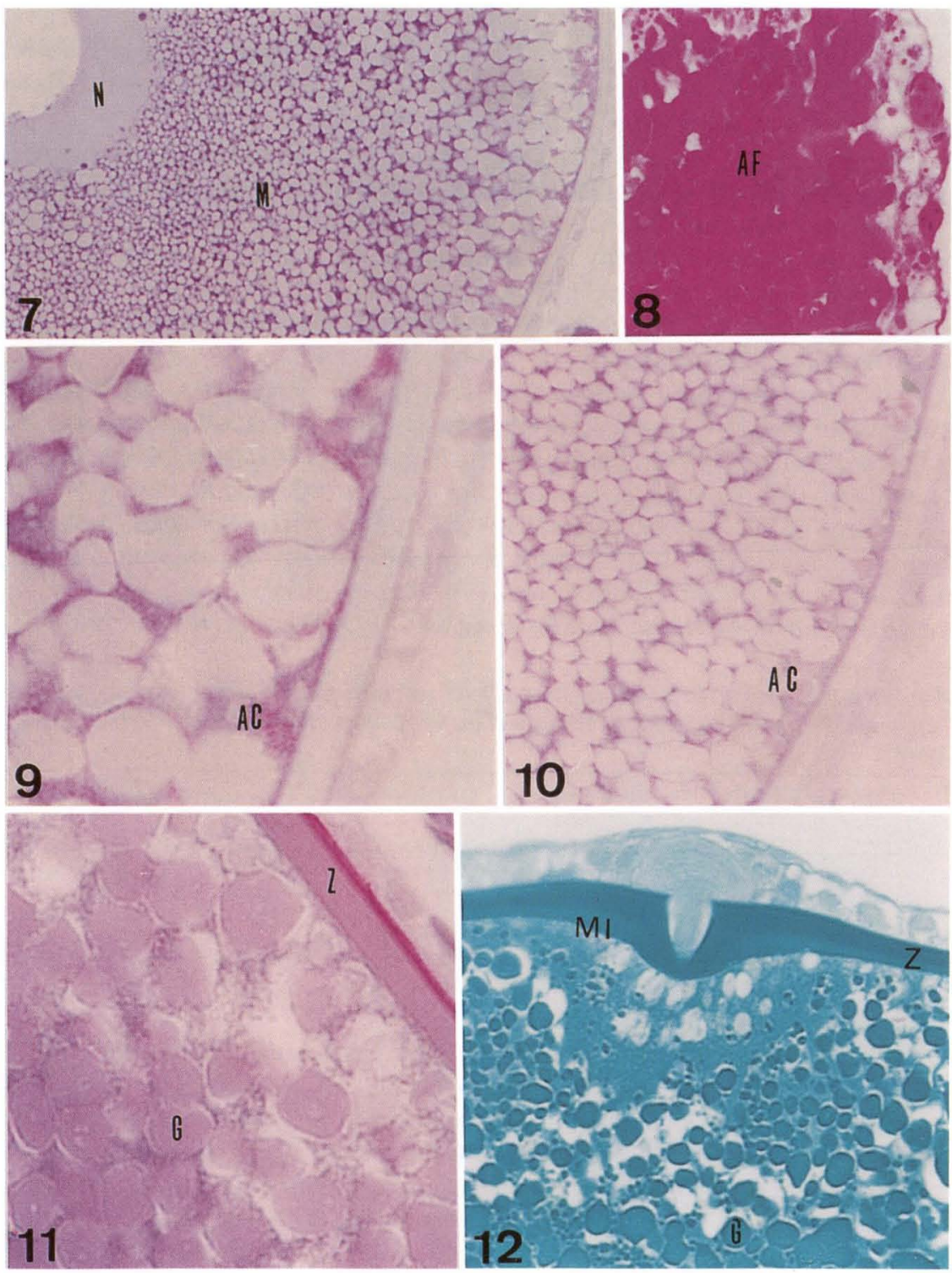

Figs 7-12. (7) mature oocyte (M), nucleus (N), AT 4.0; (8) atresic follicle (AF), HE; (9) cortical alveoli (AC), AT 4.0; (10) cortical alveoli (AC), AT 2.5; (11) yolk globules (G), zona radiata (Z), MC; (12) mycropile (MI), yolk globules (G), zona radiata (Z), FG.

cells, became cuboidal (Fig. 6). The follicle epithelium is also cuboidal in Serrasalmus brandtii Reinhardt, 1874, Acestrorhynchus britiskii Menezes, 1969 and Schizodon knerii (Steindachner, 1875), but it may be squamous in other species of fish (BAzZoli \& Rizzo 1990). In Prochilodus affinis Reinhardt, 1874, the squamous 
follicle epithelium appears enveloped by a thin layer of conjunctive tissue, the theca (Rizzo \& BAzzoli 1993). According to VAzzoleR (1996), in freshwater fishes these oocytes are ready to be eliminated from the follicle.

In this work, atresic follicles were occasionally observed in the ovaries of $L$. striatus. These structures resulted from non-ovulated mature oocytes, in which there was loss of cellular turgescence and rupture of zona radiata. Yolk globules, when present, lost their individuality becoming amorphous masses of acidophilic substances with disintegrated nuclei (Fig. 8). According to NAGAHAMA (1983), DE VLAMING (1983) and TYLER \& SUMPTER (1996), numerous follicle atresia may arise from environmental stress.

The cytochemical analysis (Tab. I) of L. striatus oocytes revealed positive response to TB pH 4.0 and $\mathrm{TB} \mathrm{pH} 2.5$ in cortical alveoli, indicating the presence of sulphated acid polysaccharides (Figs 9-10). In specimens of Hemmigrammus marginatus Ellis, 1911, Moenkhausia costae (Steindachner, 1907) and Roeboides xenodon (Reinhardt, 1851), BAZZOLI et al. (1996) observed the presence of neutral glycoproteins in these structures. The cortical alveoli also contain neutral glycoproteins in Lophiosilurus alexandri Steindachner, 1876, and carboxylated acid glycoconjugates in Pseudoplatystoma coruscans (Spix \& Agassiz, 1829) (BAZZOLI \& GODINHO 1997).

Table I. Cytochemical reactions in cortical alveoli, yolk globules and zona radiata in Leporinus striatus, collected in Rio Sapucaí, tributary of the Rio Grande, Furnas Reservoir, Mina Gerais, Brazil.

\begin{tabular}{lllll}
\hline Cytochemical reactions & Cortical alveoli & Yolk globules & \multicolumn{2}{c}{ Zona radiata } \\
\cline { 4 - 5 } & & & OL & IL \\
\hline Coello's method & - & Purplish blue & Magenta & Rosy \\
Fast Green PH 2.5 & - & Green & Green & Green \\
Toluidin Blue PH 4.0 & Rosy & - & - & - \\
Toluidin Blue pH 2.5 & Rosy & - & - & - \\
\hline
\end{tabular}

(OL) Outer layer, (IL) inner layer, (-) no response.

In Oligosarcus argenteus Günther, 1864, NEVES et al. (1995), using TB pH 3.0 and 4.0, observed metachromasia in TB pH 3.0 indicating the presence of sulphated and non-sulphated acid polysaccharides in cortical alveoli. In specimens of Leporinus Agassiz, 1829, BAZzoli \& GodinHo (1994) observed that these structures contained carboxylated acid glycoconjugates in some species and neutral glycoproteins in others. Cortical alveoli were shown to be sudanophobic in Leporinus sp., using Sudan Black B, Sudan III, Oil Red O and Nile blue sulphate (BAZZOLI \& GODINHO 1994).

In Serrasalmus brandtii, these structures are positive to $\mathrm{AB} p \mathrm{pH} 2.5$ and $\mathrm{AB}$ $\mathrm{pH} 0.5$ indicating the presence of carboxylated and sulphated acid polysaccharides or sulphated groups only. In these species, the cortical alveoli respond negatively to the lipid detection techniques (BAZzOLI \& RIZZO 1990).

The yolk globules of vitellogenic oocytes of $L$. striatus respond positively in blue to CM, and also to FG, indicating their protein content (Figs 11-12). BAzZOLI et al. (1996) observed the presence of neutral glycoproteins and neutral lipids in the 
yolk globule of $H$. marginatus, $M$. costae and $R$. xenodon. In L. alexandri and $P$. coruscans the yolk globules, besides containing neutral glycoproteins, are positive to Sudan Black B, Sudan III, Oil Red O and Nile blue sulphate techniques, indicating the presence of neutral lipids (BAZZOLI \& GoDINHO 1997).

In $L$. striatus, the zona radiata showed 2 layers that reacted differently to the staining used. With CM the outer layer stained magenta and the inner layer stained rosy; with FG, both responded in green, thus indicating their glycoproteinic content (Figs 11-12). BAzzoli et al. (1996) detected neutral glycoproteins in the zona radiata of $H$. marginatus, $M$. costae and $R$. xenodon. In the outer layer of the zona radiata of $M$. costae, they have also detected carboxylated acid glycoconjugates, and in $H$. marginatus glycoproteins rich in sialic acid. The same authors have shown that in $L$. alexandri and $P$. coruscans, the zona radiata is composed by only one layer containing neutral glycoproteins.

The chemical composition of the different oocytes structures and the oogenesis dinamics in Leporinus striatus is similar to the ones observed in other freshwater teleosts with external fertilization, according to the idea that the female gametogenesis in Teleostean fishes is linked to the reproductive tactics of the species.

ACKNOWLEDGEMENTS. The authors are grateful to Mr. Antônio Vicente Salvador and Mr. Ricardo André dos Santos for the technical help, and to Dr. Francisco Langeani Filho for identifying the specimens. Funds supporting this study were provided by FAPEMIG, Hidroelétrica de Furnas and UNIFENAS.

\section{REFERENCES}

ANDERSON, E. 1968. Cortical alveoli formation and vitellogenesis during oocyte differentiation in the pipefish, Syngnathus fuscus and the killifish. Fundulus heteroclitus. Jour. Morphol. 125: 23-60.

Bazzoli, N. \& E. Rizzo. 1990. A comparative cytological and cytochemical study of the oogenesis in ten Brazilian teleost fish species. Eur. Arch. Biol. 104 (4): 399-410.

Bazzoli, N \& H.P. Godinho. 1994. Cortical alveoli in oocytes of freshwater neotropical teleost fish. Boll. Zool. 61 (4): 301-308.

1995. Comparative morphology of the yolk nucleus (Balbiani body) in freshwater neotropical teleost fish. Rev. Brasil. Biol. 55: 207-214.

— 1997. Ovócitos vitogênicos do surubim Pseudoplatystoma coruscans e do pacamã Lophiosilurus alexandri. Coleção Meio Ambiente, Belo Horizonte, 19: 81-90.

Bazzoli, N.; E. Rizzo; G.B. SANTos \& J.E.Y. SATo. 1996. Dinâmica da ovogênese em peixes forrageiros da represa de Três Marias, Minas Gerais: estudo histológico e histoquímico. BIOS, Belo Horizonte, 4 (4): $5-10$.

Bristski, H.A. 1972. Peixes de água doce do Estado de São Paulo: Sistemática, p. 79-108. In: S.M. Branco (Ed). Poluição e Piscicultura. São Paulo, Faculdade de Saúde Pública USP, Instituto de Pesca, 216p.

CoEllo, S.A. 1989. New staining schedule for formalin-fixed, glicol methacrylate- embedded fish ovaries. Jour. Fish Biol. 34: 329-330.

DE Vlaming, V. 1983. Oocyte development patterns and hormonal involvements among teleost, p. 176-199. In: J.C. Rankin; T.J. PitcheR \& R.T. Duggan (Eds). Control processes in fish physiology. London, Croom Helm, 287p.

GURAYA, S.S. 1986. The cell and molecular biology of fish oogenesis. Basel, H.W. Sauer, 223p.

HiBIYA, T. 1983. An atlas of fish histology: normal and pathologic features. Tokyo, Kodasha. 
KARNOVSKY, J.M. 1964. A formaldehyde-glutaraldehyde fixative of high osmolarity for use in Eletron Microscopy. Jour. Cell Biol. 27: 137.

Nagahama, Y. 1983. The functional morphology of teleost gonads. p. 223-276. In: W.S. HoAR; D.J. Randall \& E.M. Donaldson (Eds). Fish Physiology. New York, Academic Press, Vol. 9, 338p. NeVEs, C.A.; D.R. Andrade; S.L.P MatTa; M.V. Vidal \& A.A. Santos. 1995. Cytochemical analysis of polysaccharides from the cortical alveoli of the oocytes of the lambari-bocarra (Oligosarcurs argenteus Günther, 1864) (Pisces, Characidae). Rev. Brasil. Biol. 55: 693-696.

Nomura, H. 1984. Dicionário dos peixes do Brasil. Brasília, Editerra, 482p.

Rizzo, E. \& N. BAzzoli. 1993. Oogenesis, oocyte surface and micropylar apparatus of Prochilodus affinus Reinhardt, 1874 (Pisces, Characiformes). Eur. Arch. Biol. 104: 1-6.

Selman, K. \& R.A. Wallace. 1989. Cellular aspects of oocyte growth in teleosts. Zool. Scien. 6: 211-231.

SILVA, J.P.D.; A.M.P. FILHo \& N.S.D. REIS. 1998. Caracterização macro e microscópica dos ovários do bagre amarelo, Cathorops spixii (Agassiz, 1829), durante o ciclo reprodutivo. Rev. Brasil. Oceanogr. 46 (2): 171-185.

SumPter, J.P.; A.P. SCOTt; S.M. BAynes \& P.R. WintTAMEs. 1984. Early stages of the reproductive cycle in virgin female rainbow trout (Salmo gairdneri Richardson). Aquaculture 43: 235-242.

Tyler, C.R. \& J.P. Sumpter. 1996. Oocyte growth and development in teleosts. Rev. Fish Biol. Fish. 6: $287-318$.

VAzzolER, A.E.A.M. 1996. Biologia da reprodução de peixes teleósteos. Teoria e Prática. Maringá, EDUEM, 169p.

Wallace, R.A. \& K. Selman. 1981. Celular and dynamic aspects of occyte growth in teleosts. Amer. Zool. 21: 325-343.

WESt, G. 1990. Methods of assessing ovarian development in fish: a review. Aust. Jour. Mar. Freshw. Res. 41 (2): 199-222.

Yамомото, K. \& H. YoshiokA. 1964. Rhythm of development in the oocyte of medaka, Oryzias latipes.

Bull. Fac. Fish. Hokkaido Univ. 15 (1): 50-19.

ZanuY, S. 1987. Reproduction en aquacultura. Madrid, Caicyt.

Recebido em 31.VIII.2000; aceito em 15.X.2001. 